УДК: 75.046

ББК: 85.14

A43

DOI:10.18688/aa166-2-19

Panayotis L. Vocotopoulos

\title{
Renaissance Influence on Post Byzantine Panel Painting in Crete
}

Constantinople, the capital of the Eastern Roman Empire, which had been the cultural centre of Eastern Christianity since the $4^{\text {th }}$ century, lost this role in the $15^{\text {th }}$ century, when it was reduced to a small enclave surrounded by Ottoman possessions. It was succeeded in its role as the main cultural centre of Hellenism by the island of Crete, a Venetian territory since 1210, where the status of the local population improved greatly in the $15^{\text {th }}$ century and the political, social and financial situation became favourable to artistic creation [20, p. 8]. Frescoes, icons and miniatures dating from this period are on the whole of very high quality. They continue the trend of metropolitan painting of the $14^{\text {th }}$ century best represented by the frescoes of the Peribleptos in Mystra, characterized by balanced compositions, restrained movements, the noble features of the figures and the elaborate plasticity of the drapery.

The preference of painters working in Crete for the classical Constantinopolitan style and the adoption by them of several westernizing iconographical features have been ascribed to the presence of Constantinopolitan artists on the island but also to their familiarity with works of the Italian Renaissance. This very good knowledge of Italian painting has led to the assumption that most of these artists lived in Venice or were trained there. The study of Cretan documents in the Venetian archives, which began systematically, as far as art in Crete is concerned, only about fifty years ago, has revealed on the contrary that most Cretan painters of the $15^{\text {th }}$ century were based in their home island and had been taught their art there ${ }^{1}$. Most of them had their workshops in the capital, Candia, the modern Herakleion. About 100 painters were attested there in the $15^{\text {th }}$ century, when its population amounted to 20000 inhabitants, and about 200 in the following century. They did not need to travel to Italy to become familiar with Renaissance art. A great number of Italian paintings could be studied not only in catholic churches and monasteries or in public buildings but also in private houses. We know e.g. that two members of the Cretan upper class, Anthony and Matthew Calliergis, acquired in Western Europe Italian and Flemish panels and collected ancient sculptures and inscriptions. Italian artists were employed on the island, and Italian and Flemish engravings circulated freely $[3$, p. 116].

Of course, some Cretan painters were active in Venice since the $14^{\text {th }}$ century and became more numerous in the $16^{\text {th }}$ century, when the several thousand Greeks living there were at last

On painting in Crete in the $15^{\text {th }}$ and $16^{\text {th }}$ century see: [3, pp. 69-124; 2, I, pp. 73-92; 5]. 
allowed to found a confraternita and to build a church ${ }^{2}$. However, they did not form a separate school and were influenced by Italian art less than most Western artists, for example those of the School of Fontainebleau. The terms Italo-cretan or Veneto-cretan school sometimes used to characterize the whole of the art of the painters working on the island are misleading and should be applied only to works inspired directly from Italian models, such as representations of the Pietà, the numerous icons of the Virgin of the type known as Madre della Consolazione, preserved mainly in Italy, or panels including saints honored especially by the Catholic Church and following Italian models, such as the Dormition of the Virgin adhering to Orthodox iconography but flanked by Sts. Dominic and Francis of Assisi, now in the Pushkin Museum in Moscow [3, pp. 81-85; 4, pp. 687-688].

The island of Crete and especially Candia exported icons, illuminated manuscripts and wooden sculptures not only to the Orthodox foundations in the Venetian and Ottoman territories of the Eastern Mediterranean, but also to the West. Icons were especially popular in Italy and Dalmatia, Catholic lands, where Byzantine culture was respected and appreciated and where many faithful preferred them to the innovative paintings of the Renaissance. Cretan artists also painted panels such as pale d'altare for Catholic churches, such as an altarpiece from Santo Stefano in Monopoli (Apulia), now in the Boston Museum of Fine Arts [3, pp. 108-116; 22, pp. 9-10; 8, pp. 14-15, fig. 4]. The production of icons for a wide spectrum of clients as far as dogma, nationality, and taste are concerned, compelled the Cretan artists to acquire the skill to follow diverse models, a la greca or a la latina, or to combine the two traditions, according to the wishes of their customers [3, p. 109, fig. 7]. Cretan artists were already famous in the $15^{\text {th }}$ century and some of them proudly pointed their origin in their signature.

The miniatures of a Latin manuscript of the Walters Art Museum of Baltimore (Walters 335), written and decorated on Crete in 1415, bear witness to a very high level of Cretan art at an early stage and to the virtuosity of Cretan artists in both the Italian and the Byzantine style. The figures of St. John the apostle and of his disciple Prochoros are typically Byzantine, but are framed by a finely executed Gothic floral ornament [3, p. 109, fig. 87, with previous bibliography].

The ability of Cretan painters to produce Byzantinising or Italianate compositions or to combine the two styles is illustrated by three paintings by Andreas Pavias, active in the last quarter of the $15^{\text {th }}$ century. His icon of St. Anthony, now in Cephallonia, is free of any western influence in its style and iconography. The only western feature of the Virgin and Child, today in the Campo Santo Teutonico in the Vatican, is the punched vegetal decoration of the haloes, typical of Italian art. In his Crucifixion in the National Gallery in Athens, Pavias draws his inspiration from Late Gothic representations of the Calvary. This panel is signed in Latin (in the lower right-hand corner), as is also the Pietà by the same artist in the Cathedral of Rossano, while elsewhere Pavias signs in Greek proudly mentioning in a few cases his Cretan origin:

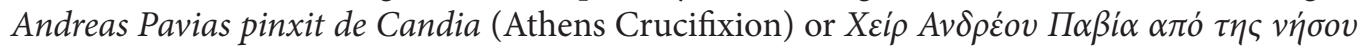

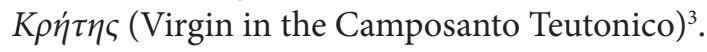

2 San Giorgio dei Greci was built between 1539 and 1577. On Greek painters attested in Venice in the $15^{\text {th }}-17^{\text {th }}$ cent., cf.: $[7$, pp. $569-601]$.

On Pavias see: [3, pp. 90-98; 20, pp. 9-10; 2, II, pp. 259-264]. On the icon of St. Anthony: [2, II, fig. 168]; on that of the Campo Santo Teutonico: [2, II, fig. 175]; on the Crucifixion in Athens: [2, II, fig. 172173; 8, pp. 64-65]. 
Western features sometimes encountered in Cretan paintings of the $15^{\text {th }}$ century include Italianate buildings, misty landscapes, animals rendered naturalistically, marble thrones with inlaid decoration, punched haloes, but also in some cases placing the signature in a kind of frame, as in the Crucifixion of Pavias in Athens ${ }^{4}$. In the panel of Jesus carrying the Cross in the Metropolitan Museum, signed by Nikolaos Tzafouris, a Cretan painter of the late $15^{\text {th }}$ century, the image of Christ and the landscape are Byzantine, while the armour of the soldier dragging the Lord is Western and the men of his escort resemble Trecento figures. The same confusion

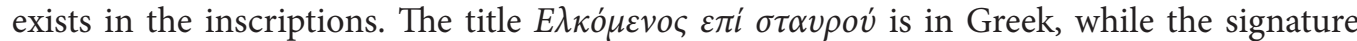
Nicolaus Zafuri pinxit is in Latin $^{5}$.

Sometimes traditional paintings have a Gothic frame. The $15^{\text {th }}$ century iconostasis door in the monastery of Patmos representing the Annunciation, St. Peter and St. John the Evangelist, to whom the monastery is dedicated, is topped by a woodcarving of the prophet David, which is reminiscent of the decoration of Venetian polyptychs of the late $14^{\text {th }}$ and first half of the $15^{\text {th }}$ century ${ }^{6}$. In several cases, Byzantine and Italian scenes and figures are painted side by side, retaining their distinct characteristics as in the Monopoli altarpiece in Boston or in the Dormition of the Virgin flanked by Sts. Dominic and Francis of Assisi, of the Pushkin Museum, already mentioned.

The arrangement of the composition of some panels, with a central group twice as large as the scenes and standing figures which flank it on two sides, is inspired by Italian Renaissance paintings [23, pp. 143-146].

The shape of icons was also sometimes influenced by Western models, and this applies also to Cypriot panels. The pointed upper side of some late $15^{\text {th }}$ century icons such as a Deisis by Nikolaos Tzafouris in Corfu [8, pp. 60-61] recurs often in $15^{\text {th }}$ century Italian works. Some panels were round. Western influence is not limited to iconography or the shape of panels but extends to technique. The partial use of oil in some of the icons by the painter Angelos Akotantos, active in the second quarter of the $15^{\text {th }}$ century, has recently been established.

Characteristic of Cretan painting in the $15^{\text {th }}$ century is the crystallization of many subjects, which are repeated with minor changes for the next two centuries. The use of working drawings handed down from generation to generation, sold or lent, certainly contributed to this phenomenon. Most of these subjects derive from Late Palaeologan art, for example a variant of the Entry into Jerusalem, with Christ on the right and the apostles following him partly hidden, and the Harrowing of Hell where Christ walks rapidly towards the right and holds a closed roll instead of a cross. The model for this variant is to be found in the church of the Peribleptos at Mistra $^{7}$ (Ill. 46, 47).

One also encounters subjects inspired by Italian models such as the Noli me Tangere, where Mary Magdalene has long blond hair and a red cloak with fluid drapery, characteristic of International Gothic art of the early $15^{\text {th }}$ century [20, pp. 23, 81]. It is noteworthy that Cretan

4 On western influences on Cretan painting cf.: [2, pp. 75-81, 111-115; 12, pp. 51-67].

5 On Tzafouris see: [3, pp. 86-90; 2, I, pp. 292-294, II, p. 434]. On the New York panel see: [2, I, fig. 164; 8, p. 62].

6 Patmos iconostasis door: [2, pp. 71-72, fig. 46-47]. On the Venetian polyptychs see: [11, pls. 35, 39, $115,144,146,148,158,208]$.

7 On the Leucas panel see: [22]; on the Corfu one: [20, pp. 28-31]. 
painters of the $15^{\text {th }}$ century prefer models of Trecento instead of contemporary ones. There are also subjects which appear in the $15^{\text {th }}$ century as the apostles Peter and Paul holding together the model of a church that is reminiscent of Italian Renaissance churches. This subject has been linked with the Council of Ferrara-Florence and the unionist sympathies of its creator.

One must not deduce that Cretan painters of the $15^{\text {th }}$ century did not invent new subjects. An Allegory of the Heavenly Jerusalem, now in Corfu, combines traditional motifs, such as the monks walking towards Jerusalem, and western ones, such as the personifications of different vices in the lower part of the panel [20, pp. 19-22] (Ill. 48). Allegorical figures riding on a chariot are common in Italian art during the second half of the $15^{\text {th }}$ century. The Corfu panel can be dated to the turn of the $16^{\text {th }}$ century, thanks to the group of young girls coming out of a city at the lower left corner. They were copied from the engraving by the Venetian artist Zuan Andrea, who repeats the Dance of the Muses in the painting of Parnassus by Mantegna, dating from about $1497^{8}$.

Italian influence is not limited to style and iconography. From the early $16^{\text {th }}$ century on, templa are crowned with a wooden cross with a depiction of the crucified Savior. Such crosses are attested in Venetian painting since the $14^{\text {th }}$ century. They disappear from Italy at the end of the $15^{\text {th }}$ century, while they are still used in Greek churches [13, pp. 105-112].

Cretan influence can be traced in works of Orthodox painters of other nationalities; for example, in Serbian liturgical books printed in the $16^{\text {th }}$ century in Venice $[14 ; 19]$.

In the $15^{\text {th }}$ century large numbers of Cretan icons were exported to the west, especially Italy, where conservative patrons held them in high regard, as adhering more closely to the original Christian art, than the innovative panels of the Renaissance [3, pp. 81-85; 4, pp. 687-688]. This great demand for Cretan icons seems to have greatly decreased during the $16^{\text {th }}$ century.

Various degrees of Renaissance influence can be detected in the work of the three most important Cretan artists of the $16^{\text {th }}$ century. Michael Damaskinos, born in the 1530s, was influenced by Italian mannerism [2, I, pp. 241-254; 20, pp. 38-61; 6, pp. 1223-1246; 7, pp. 581588]. He spent several years in Italy, where he decorated the newly erected church of San Giorgio dei Greci in Venice. In many of his works he adheres to Byzantine formulas, as they were crystallized in Crete during the previous century, for example, in an icon of St. Anthony now in Corfu [20, pp. 47-48] (Ill. 49). Other panels of this artist are greatly influenced by contemporary Italian painting. In the Beheading of St. John, instead of following traditional models, he imitates Italian pale d'altare with martyrdom scenes (Ill. 50). The two Hebrews in front are copying two figures of the Martyrdom of Sts. Primus and Felicianus by Veronese. The dresses of Salome and her attendants and the armour of the commanding officer and the executioner follow contemporary Italian models [20, pp. 51-53].

The victory of the Christian fleets over the Ottomans near Lepanto in 1571 inspired many artists, both in Italy and in Crete. While these painters - among them Veronese and Tintoretto - represented the battle itself [16, pp. 279-287], Damaskinos painted saints Sergius, Bacchus and Justina, whose feast is on October 7, the day of the battle, trampling a dragon who alludes to the Ottomans (Ill. 51). The three saints are inspired by contemporary Venetian painting [20, pp. 48-50]. 
Damaskinos painted several Gospel scenes, incorporating many Italian features, for example the Adoration of Magi [8, pp. 94-105, No. 34-39]. It has been argued that these panels were intended for a Catholic public. The fact that these Italianate panels were preserved in an Orthodox monastery - that of Vrontissi, south of Heraklion - proves that not only members of the Greek middle and upper class, permeated by Italian culture, appreciated Italianate art, but also the orthodox clergy of Crete.

Another important artist, George Klontzas, is mentioned between 1562 and 1608 [15; 2, II, pp. 83-96]. He was both a panel and a miniature painter. Klontzas was well known at an early age, since he was designated in 1566 as an expert to value a painting by Domenikos Theotokopoulos, later known as El Greco. He rarely painted traditional subjects, as the enthroned Virgin in the Museum of Zante. He specialized in small-scale crowded compositions, with many secondary episodes, in-

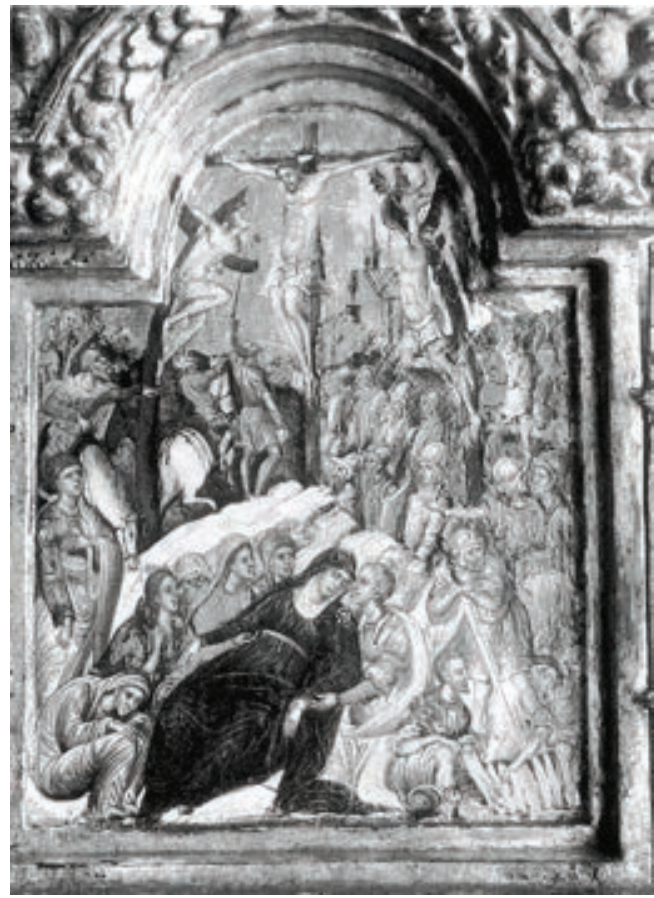

Fig. 1. George Klontzas. Crucifixion.

Panel of a triptych in the Cathedral of Osimo.

Photo by P. Vocotopoulos fluenced by contemporary Italian painting. Many of these are triptychs. One of his favorite subjects was the Last Judgement, inspired by the composition of Michelangelo in the Cappella Sistina. He sometimes includes contemporary figures in his compositions, as in the Last Judgement in Corfu, where the man with contemporary dress pictured among the saints is perhaps his own portrait [20, pp. 63-66] (Ill. 52). In an excellent triptych with the Crucifixion, now in Osimo, in Central Italy, a woman comforting the Virgin wears an elegant contemporary dress. She is most probably the donor (Fig. 1). The fact that one panel of the triptych is painted with scenes from the Life of St. Anne, which are not at all common in such a context, may be due to the fact that this was the name of the donor [21, pp. 431-438].

The third important painter of this generation, Dominikos Theotokopoulos, was also born and raised in Candia, but left his native island in 1567 for Venice, then Rome and finally Spain where he remained until his death and became famous under the name of El Greco, the Greek. A few panels are assigned to his early years in Crete, among them an icon of the Dormition of the Virgin now on the island of Syros with a traditional iconography, except for some details, such as the candelabrum with three figures at the front ${ }^{9}$.

Most of the painters of the first decades of the $17^{\text {th }}$ century do not follow the stylistic and iconographic innovations of Damaskinos and Klontzas and return to models of the $15^{\text {th }}$ and

9 On the Cretan period of El Greco see: [17, pp. 1-121; 9]. On the Syros icon: [1, pp. 29-44; 8, pp. 108-
109]. 
early $16^{\text {th }}$ century. They obviously followed the prevailing public taste. Jeremias Palladas, an artist active in the first quarter of the $17^{\text {th }}$ century, was admired, according to the Patriarch of Jerusalem Nektarios, because "he could be compared to the best ancient painters, whose work he imitated more than anybody else."

The last phase of Cretan panel painting covers the years from the 1640s to the end of the century, when the last painters educated in Candia, which surrendered to the Turks in 1669, died in exile. During these years both innovative and conservative tendencies exist side by side. The more important artists usually closely follow western models. Theodore Poulakis, born in Chania and active in Venice and the Ionian islands, is often inspired by Flemish engravings, as in a big panel with the Ascension of the Prophet Elias framed by small scenes from his life. In this work he follows an engraving by Jan Sadeler ${ }^{10}$. Both his works and those of Emmanuel Tzanes, a learned priest from Rethymnon who fled his home city when it was taken by the Turks in 1646 and established himself first in Corfu and then in Venice, are distinguished by their precise drawing with many thin white highlights and the adjunction of secondary scenes [20, pp. 104-108; 2, II, pp. 408-423]. Tzanes innovated in the representation of holy bishops, whom he depicts dressed in contemporary liturgical vestments (Ill. 53). $\mathrm{He}$ is at the same time influenced by $15^{\text {th }}$ century Italian art. He painted, for example, marble thrones with pillars where miniature figures are seated, and saints wearing embroidered vestments reminiscent of works by Crivelli.

Among other Cretan painters of this period, Victor and Philotheos Skouphos acquired a fame which is not in proportion with their capabilities. They apparently owed it, like Jeremias Palladas, to the successful imitation of older models, mainly the works by Michael Damaskinos $^{11}$. Victor painted the standard of the flagship of Francesco Morosini, the last Governor of Crete, now in the Museo Correr in Venice. This is an indication that he was the best painter available in the besieged city [24, pp. 268-275].

The tradition of the Cretan painters educated on their native island was taken up by artists of the Cretan diaspora and painters from the Ionian Islands. The lack of apprenticeship in an important artistic centre is evident in their works. From the second quarter of the $18^{\text {th }}$ century the Cretan tradition is abandoned in favour of the Italian baroque style.

Panel painting in Crete in the $15^{\text {th }}$ to $17^{\text {th }}$ centuries was part of the flowering of the arts during the last two and a half centuries of Venetian domination which included also sculpture, wood-carving and literature. Without betraying their Greek nationality and Orthodox dogma, Cretans developed a civilization, in which traditional Byzantine and imported western features blended harmoniously. Crete is practically the only Greek region which adopted the ideals of the Renaissance. Painters of the Cretan school retained till the advent of the baroque style several technical and aesthetic principles of Byzantine painting, which they enriched with western stylistic and iconographic features. Thanks to their high quality and their adherence to the Orthodox dogma, their works became a model for Greek, Slav and Arab artists alike. 
Title. Renaissance Influence on Post Byzantine Panel Painting in Crete.

Author. Panayotis L. Vocotopoulos - Ph. D., member of the Academy of Athens, professor. Panepistimiou, 28, 10679 Athens, Greece. dim@academyofathens.gr

Abstract. During the $15^{\text {th }}-17^{\text {th }}$ centuries the Greek island of Crete, then a Venetian colony, developed a school of painting stemming from the Palaeologan tradition but enriched by stylistic and iconographic elements taken from the Italian Renaissance. The paper examines the channels by which Italian features were absorbed by Cretan painters, the importance of these features which varied from painter to painter and from period to period, the dogma to which the artists belonged, nationality and social status of sponsors, the geographical area where Cretan works were exported, new subjects adopted by Post-Byzantine artists, the framing of paintings, and several other aspects of this refined art which vanished with the Conquest of the island by the Ottomans in the late $17^{\text {th }}$ century.

Keywords: postbyzantine painting; panel painting; Crete; Renaissance influence.

Название статьи. Влияние Ренессанса на поствизантийскую иконопись Крита.

Сведения об авторе. Вокотопулос Панайотис - Ph. D., член Афинской академии наук (Греция), профессор. Панепистимиу 28, Афины, Греция, 10679. dim@academyofathens.gr

Аннотация. B XV-XVII вв. на греческом острове Крит, который был тогда венецианской колонией, возникла школа живописи, опирающаяся на палеологовскую традицию, но обогатившаяся стилистическими и иконографическими заимствованиями из искусства итальянского Ренессанса. В работе исследуются пути, которыми элементы итальянской живописи приходили к критским художникам; значение этих элементов, различавшихся в зависимости от мастера и периода его творчества; художественные концепции тех или иных мастеров; национальная и социальная принадлежность заказчиков; географическое распространение критских икон, производившихся на экспорт; новые сюжеты, воспринятые поствизантийскими мастерами, и многие другие аспекты, связанные с этим изысканным искусством, которое угасло с завоеванием Крита турками в конце XVII в.

Ключевые слова: поствизантийская живопись; иконопись; Крит; ренессансное влияние.

\section{References}

1. Achimastou-Potamianou M. Domenikos Theotokopoulos: The Dormition of the Virgin, a Work of the Painter's Cretan Period. El Greco of Crete, Proceedings of the International Symposium, Iraklion, Crete, 1-5 September, 1990. Heraklion, 1995, pp. 29-44.

2. Chatzidakis M. Ellines zographoi meta tin Alosi (1450-1830) (Greek Painters after the Fall of Constantinople). Athens, EIE Publ., 1, 1987, 342 p.; 2, 1997, 468 p. (in Greek).

3. Chatzidakis M. Essai sur l'école dite italogrecque précédé d'une note sur les rapports de l'art vénitien avec l’art crétois jusqu’à 1500. Venezia e il Levante fino al secolo XV, 2. Firenze, 1974, pp. 69-124 (in French).

4. Chatzidakis M. La peinture des "Madonneri" ou "Véneto-crétoise" et sa destination. Venezia centro di mediazione tra Oriente e Occidente (secoli XV-XVI). Aspetti e problemi, 2. Firenze, 1977, pp. 687-688 (in French).

5. Chatzidakis N. From Candia to Venice. Greek Icons in Italy, $15^{\text {th }}-16^{\text {th }}$ Centuries. Athens, 1993, pp. 1-20.

6. Constantoudaki-Kitromilides M. Larte dei pittori greci a Venezia nel Cinquecento. La pittura nel Veneto. Il Cinquecento, 3. Milano, Electa Publ., 1999, pp. 1223-1336 (in Italian).

7. Constantoudaki-Kitromilides M. Le icone e l'arte dei pittori greci a Venezia. Maestri in rapporto con la confraternita greca. I greci a Venezia. Atti del Convegno Internazionale di Studio, Venezia 5-7 novembre 1998. Venezia, Istituto Ellenico Publ., 2002, pp. 569-601 (in Italian).

8. Drandaki A. (ed.) The Origins of El Greco: Icon Painting in Venetian Crete. New York, Onassis Foundation Publ., 2009. 131 p.

9. Fatourou-Hesychakis K.; Hesychakis M. Cretan Sources of Theotokopoulos' (El Greco's) Humanism. Athens, National Bank of Greece Publ., Cultural Foundation, 2004. 97 p.

10. Hind A. M. Early Italian Engraving, 5. London, Quaritch Publ., 1948. 347 p.

11. Humfrey R. The Altarpiece in Renaissance Venice. New Haven - London, Yale University Press Publ., 1993. $352 \mathrm{p}$.

12. Kazanaki-Lappa M. He zografiki stin Kriti (1350-1669). He vizantini paradosi kai i skhesi me ti dytiki tekhni (Painting in Crete (1350-1669): The Byzantine Tradition and the Influence of Western Art). Cretan Studies, 1998, 6, pp. 51-70 (in Greek). 
13. Kazanaki-Lappa M. Le croci dipinte d'iconostasi cretesi e i loro modelli veneziani. Il contributo veneziano nella formazione del gusto dei greci (XV-XVII sec.). Venice, Istituto Ellenico Publ., 2001, pp. 105-112 (in Italian).

14. Medaković D. Die Graphik der serbischen Drucke vom XV. bis zum XVII. Jahrhundert. Beograd, Naučno delo Publ., 1958. 275 p. (in German).

15. Paliouras A. O zografos Georgios Klontzas (1540 ca. - 1608) kai ai mikrographiai tou kodikos autou (The Painter George Klontzas and the Miniatures of His Codex). Athens, Grigori Publ., 1977. 417 p. (in Greek).

16. Pallucchini A. Echi della battaglia di Lepanto nella pittura veneziana del '500. Il Mediterraneo nella seconda metà del'500 alla luce di Lepanto. Firenze, 1974, pp. 279-287 (in Italian).

17. Panayotakis N. He kritiki periodos tis zois tou Dominikou Theotokopoulou (The Cretan Period of the Life of Domenikos Theotokopoulos). Afieroma ston Niko Svorono (Festschrift for Nikos Svoronos), II. Rethymnon, 1986, pp. 1-121 (in Greek).

18. Rigopoulos J. O zographos Theodoros Poulakis kai i flamandiki Khalkographia (The Painter Theodore Poulakis and Flemish Engraving). Athens, Grigori Publ., 1979. 500 p. (in Greek).

19. Vocotopoulos P. L. A propos de l'influence de la peinture crétoise sur la gravure serbe du 16e siècle. Balkan Studies, 1983, 24.2, pp. 675-680 (in French).

20. Vocotopoulos P. L. Eikones tis Kekyras (Icons of Corfu). Athens, MIET Publ., 1990. 434 p. (in Greek).

21. Vocotopoulos P. L. Le triptyque d'Osimo. JÖB, 1994, 44, pp. 431-438 (in French).

22. Vocotopoulos P. L. Mia proïmi kritiki ikona tis Vaïoforou stin Lefkada (An Early Cretan Icon of the Entry into Jerusalem at Leucas). Deltion tis Cristianikis Archaiologikis Etaireias, 1977-79, 9, pp. 309-321 (in Greek).

23. Vocotopoulos P. L. Remarks on a Cretan Icon of the Sixteenth Century. Il contributo veneziano nella formazione del gusto dei Greci (XV-XVII sec.). Venezia, Istituto Ellenico Publ., 2001, pp. 143-146.

24. Vocotopoulos P. L. To lavaro tou Fragkiskou Morozini sto Mouseio Correr tis Venetias (The Flag of Francesco Morosini in the Correr Museum of Venice). Thesaurismata, 1981, 18, pp. 268-275 (in Greek). 


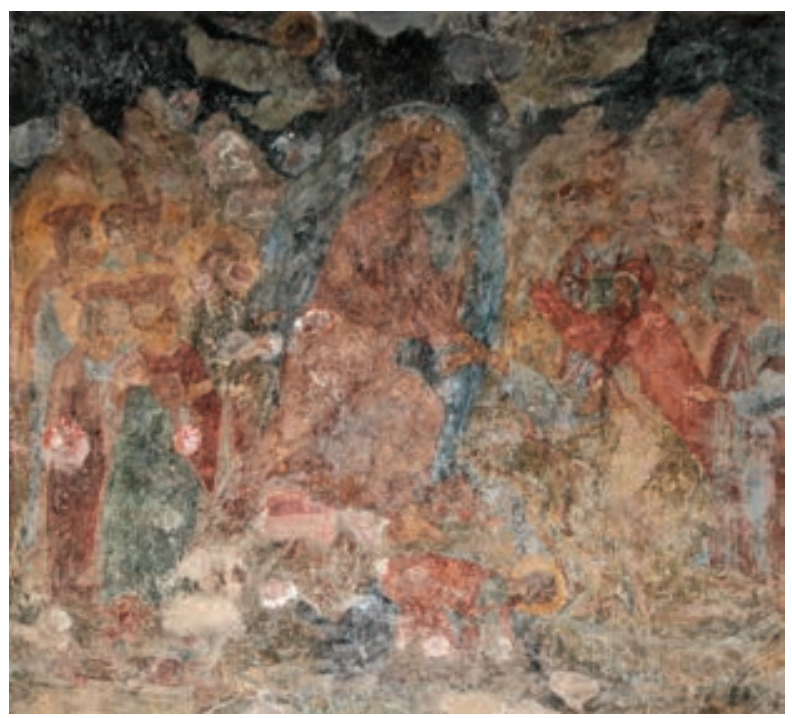

Ill. 47. Harrowing of Hell. Church of the Virgin Peribleptos, Mystras. Third quarter of the $14^{\text {th }} \mathrm{c}$. Photo by P. Vocotopoulos

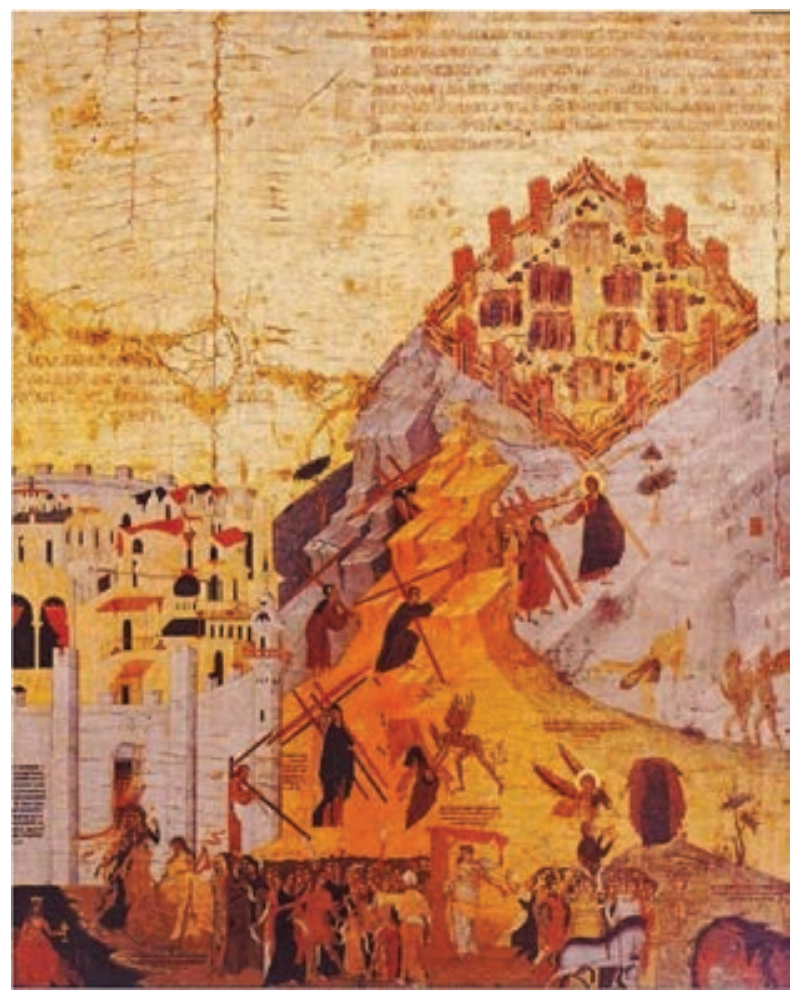

Ill. 48. Allegory of the Heavenly Jerusalem. Ca. 1500. Corfu, Monastery of the Virgin Platytera. Photo by P. Vocotopoulos

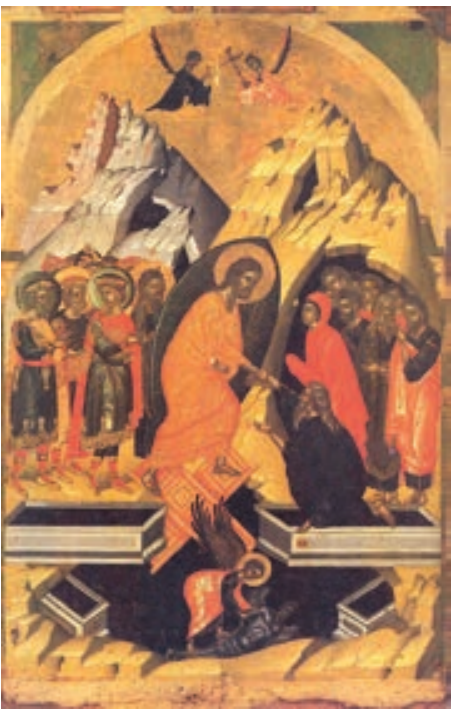

Ill. 46. Harrowing of Hell. Corfu, Antivouniotissa Museum. Late $15^{\text {th }} \mathrm{c}$.

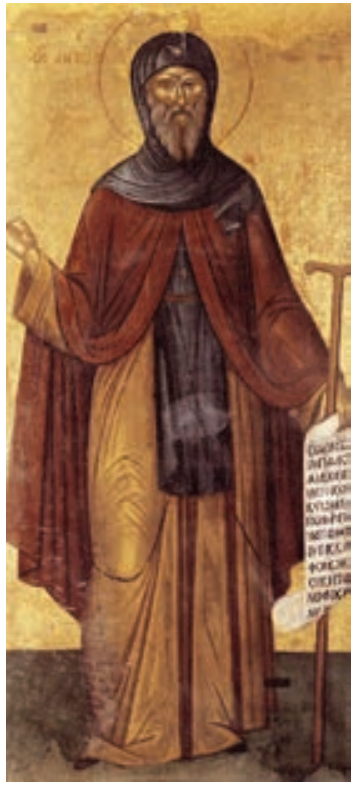

Ill. 49. Michael Damaskinos. St. Anthony. Corfu, Cemetery. Photo by P. Vocotopoulos 


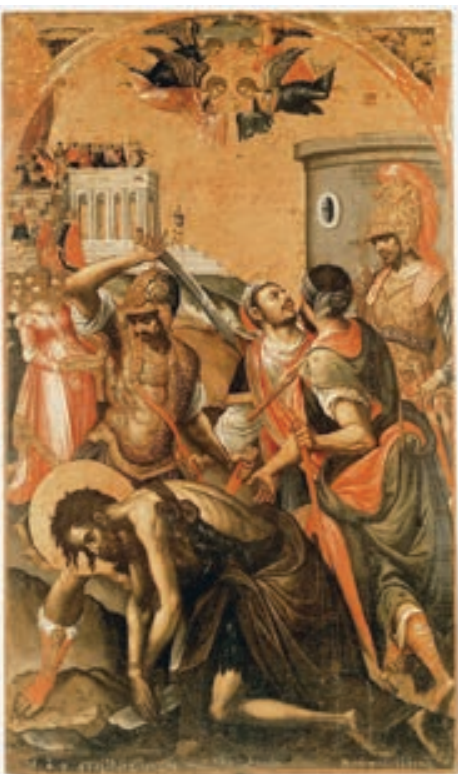

Ill. 50. Michael Damaskinos. Beheading of St. John. 1590. Corfu, Cemetery. Photo by P. Vocotopoulos

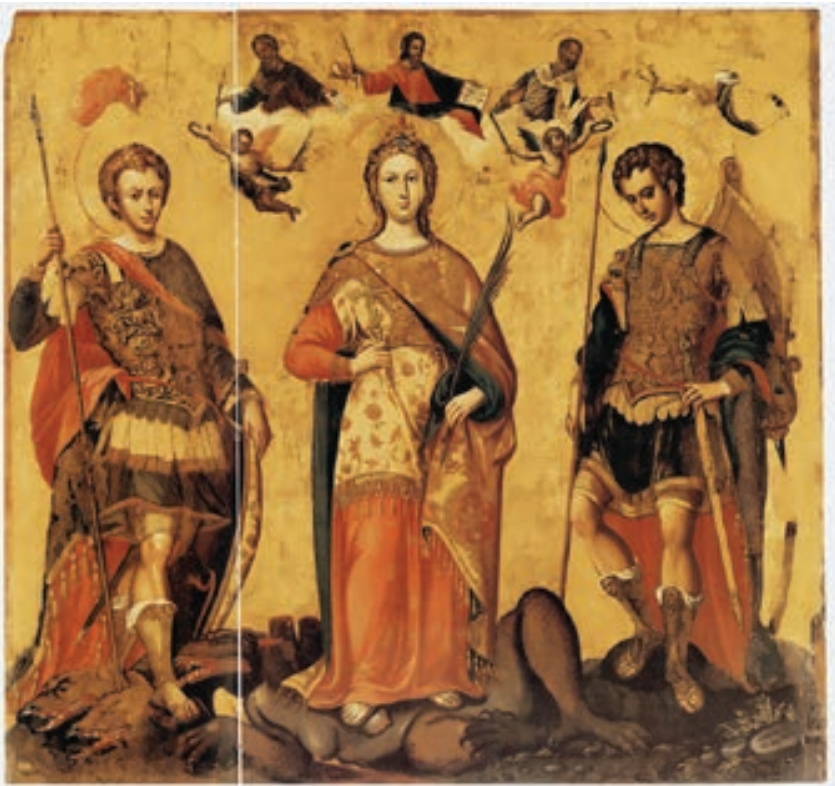

Ill. 51. Michael Damaskinos. Allegory of the Battle of Lepanto. 1570 s or 1580s. Corfu, Antivouniotissa Museum. Photo by P. Vocotopoulos

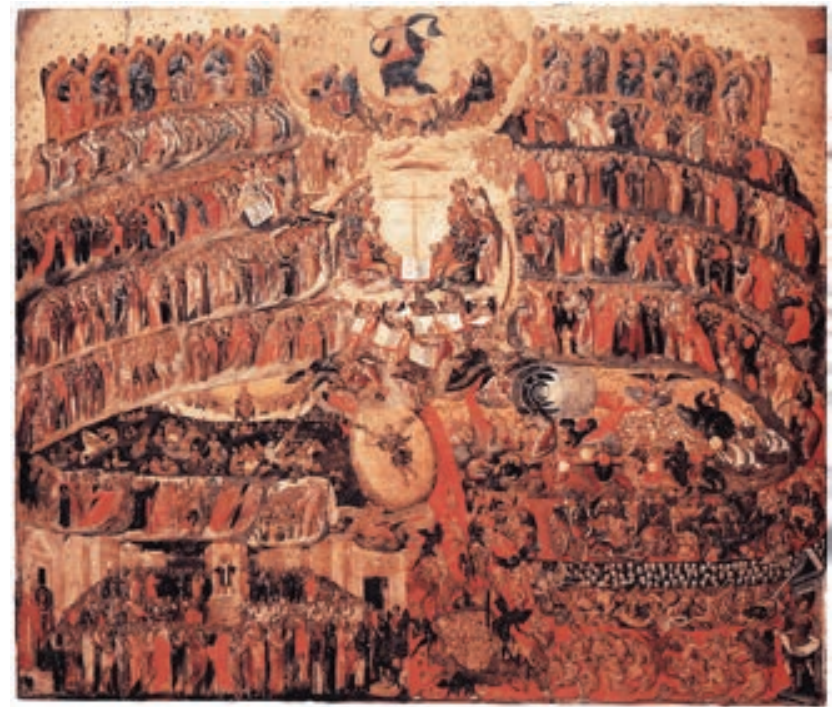

Ill. 52. George Klontzas. Last Judgement. Corfu, Monastery of the Virgin Platytera. Photo by P. Vocotopoulos

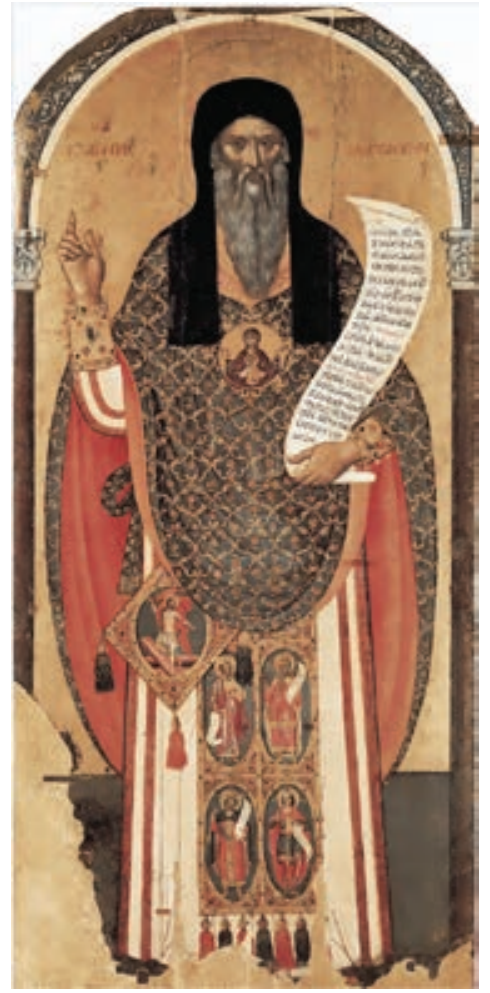

Ill. 53. Emmanuel Tzanes. St. John Damaskinos. 1654. Corfu, church of Sts. Jason and Sosipatros. Photo by P. Vocotopoulos 